Chapter 12

\title{
Microbiological Contamination of Homemade Food
}

\author{
Suzymeire Baroni, Izabel Aparecida Soares, \\ Rodrigo Patera Barcelos, \\ Alexandre Carvalho de Moura, \\ Fabiana Gisele da Silva Pinto and \\ Carmem Lucia de Mello Sartori Cardoso da Rocha
}

Additional information is available at the end of the chapter

http://dx.doi.org/10.5772/53170

\section{Introduction}

The consumption of healthy food is a consumer's right and the duty of the manufacturing industry. Health authorities are duty bound to prepare and enforce laws to protect the population's health. The supply of food free from health risks to the population is actually a challenge. In fact, contaminated food may cause serious infections and jeopardize the health of the population.

Owing to their frequency, food-caused infections are a very grave issue to public health. They may cause hazards ranging from a simple intestine discomfort to cases that are more serious, such as neurological disorders and death, because of the high number of microorganisms involved in a simple epidemic event.

Fresh or processed animal-derived food may harbor several pathogenic microorganisms that cause physiological disorders in people who consume them. When food eventually contaminated by disease-causing microorganisms is consumed, pathogens or their metabolites invade the host's fluids or tissues and trigger serious types of diseases, such as tuberculosis. They are conveyed by non pasteurized milk or by cheese contaminated by bacterial populations of Mycobacterium bovis and M. tubercolosis or by Brucella abortus, gram negative bacteria, intracellular pathogen that cause undulant fever and arthritis in human beings.

Bacteria, fungi, protozoa and viruses are the main microorganism groups that cause food disorders. Due to their diversity and pathogenesis, bacteria are by far the most important microbial group commonly associated with food-transmitted diseases. High rated agents in food 
infections are Salmonella sp., Campylobacter sp and Listeria monocytogenes due to their importance in eventual sequelae. The microbiological health risks in fowl consumption and its raw products include contamination by the above food pathogens.

Besides being one of the principal causes of food-derived diseases since its attack generally involves a great number of people, the genus Salmonella is associated with economic liabilities, commercial damage and decrease in production due to its frequency and extension. These facts occur because of the great number of food products that may be contaminated by this bacterium, namely, food with high humidity, protein and carbohydrate rates, such as beef, pork, chicken, eggs, milk and their derived products, highly liable to deteriorate. The contamination process by pathogenic bacteria in humans may be caused by poor hygiene conditions during processing involving sick people and animals or involving feces from infected agents. Bacteriacontaminated food may also be hazardous to public health due to the excessive growth in bacteria populations at food surface or within the food. These bacteria may come from the environment and cause toxins that develop into serious health problems on intake.

Hand-manipulated meat, sausages, salamis and cheese are among the most consumed products worldwide. They are also liable to high microbiological contamination due to their manufacturing process.

The World Health Organization and the Food and Agriculture Organization of the United Nations have published reports and studies developed in several regions of the planet highlighting the pathogen risks to populations and suggested the protection of food consumers through special industrial, operational, commercial and residence care. The need for great attention in food safety is a self-evident topic. In fact, improvements in food processing methods and conscience-awareness with regard to food safety by all involved in the food production chain will surely reduce the incidence of food-originated diseases.

\section{Microbiological contaminants of milk and homemade fresh cheese}

Milk is one of the most complete food featuring high levels of protein and mineral salts. However, due to the availability of nutrients and almost neutral $\mathrm{pH}$, milk is highly perishable. It is highly liable to microbial growth and requires thermal treatment for its conservation [1]. Pasteurization prolongs milk conservation time, conserves its natural characteristics and preserves it safe for human consumption. High temperatures are involved so that the product's pathogenic microbiota are eliminated with no changes in its physical and chemical constitution. However, people in rural regions still drink milk in natura and use it thus as prime matter for the manufacture of derived products.

The hygienic obtaining of milk is the first critical factor within the manufacturing process of cheese and other products. In fact, the animal, equipments and environment at milking may be an important contamination source by microorganisms [2]. Faults during milking and processing coupled to inadequate conservation temperatures at the selling outlets are factors that contribute towards the commercialization of milk products with microbiological charac- 
teristics that go against health norms and legislation [3]. The quality of milk and that of its products is a highly relevant factor for positive industrialization success since both the dairy and the consumer are interested in the outcome. In some case, however, a significant increase in the price of milk ensues. Milk is a product that should come from healthy herds, with good meals and managements, and from farms with proper technical installations that guarantee conservation during transport up to the dairy factory [4].

Since the number of milk contaminants increases at a slow rate from the moment of their introduction, the importance of adequate conservation of recently obtained milk should be underpinned as a basic practice for the maintenance of its quality. Milk should be submitted at low temperatures immediately after the milking process, with the consequent avoidance of the proliferation of unwanted microorganisms [5].

As a milk-derived product, cheese is frequently a food-originating pathogen vector. This is especially true for handmade fresh cheese manufactured from raw milk, lacking any maturation process. The product's microbial contamination is relevant for the industry because of financial liabilities, and for public health because of the risks in food-transmitted diseases.

Several studies [6] have shown that a product's quality and durability largely depend on the prime matter used in manufacturing. It is practically impossible to improve the qualities of a derived product, such as cheese, with a high number of microorganisms present in raw milk.

\section{Fresh Minas cheese}

Fresh Minas cheese (traditionally manufactured in the state of Minas Gerais, Brazil, whence its name) is defined by the Brazilian Ministry of Health (Decree 146) as fresh cheese obtained by enzyme coagulation of milk with curds and other appropriate coagulant enzymes, supplemented or not by the activity of specific lactic bacteria. According to the Technical Rules for the Identification and Quality of Milk Products [7], fresh Minas cheese may be classified as cheese with low moisture or semi-hard cheese with moisture ranging between 36 and 45.9\%; cheese with high moisture or moderate mass cheese with 46 to $54.9 \%$ moisture; and very high moisture cheese or soft mass cheese, with not less than $55 \%$ moisture.

The processing of fresh Minas cheese comprises the following stages: milk pasteurization, coagulation, cutting, draining, milling, salting, packing and cooling [8]. Since the manufacturing of this type of cheese is highly simple, many small, medium-sized and large dairies are interested in its fabrication. In fact, it is the most common type of cheese found in fairs, bars and grocers. The cheese is normally placed in a common non-vacuum plastic bag and closed by a metal seal [9].

According to the Brazilian Association of Cheese Industry (ABIQ), Brazil produces 400,000 tons of cheese per year, of which 240,000 tons are produced under federal, state and municipal inspection. Most production (95\%) is consumed by common people [10]. 
The intake of fresh cheese may be risky for the consumer's health. However, Decree 861/1984 basically prohibits the sale of fresh cheese manufactured from the raw milk of cows, goats or sheep, pure or mixed. Milk should undergo pasteurization or other equivalent thermal treatment. Current legislation was published after several registers of human brucellosis caused by fresh cheese. In defiance of the law, the homemade manufacture of cheese in certain regions of Brazil is not done with pasteurized milk. Consequently, the consumption of homemade cheese brings to the fore old dangers such as brucellosis (Maltese fever) and other infectious diseases.

In spite of the legal prohibition against the commercialization of fresh and tender cheese manufactured from raw milk, the sale of homemade fresh Minas cheese occurs openly and everywhere in Brazil [11]. This is partially due to a greater yield, simpler processing and lack of product's maturation in the fabrication of this type of cheese, with low costs for the consumer and a fast return of expenditure to the manufacturer [12].

Food protection authorities classify microbial biological contamination as a main danger to public health. Who has constantly raised its voice on the need to restrict food contamination by health-impairing biological agents. Although microbial quality of food is of paramount importance, registration at the Federal Inspection Service does not guarantee lack of pathogens in food [13].

Food-derived diseases may be caused by several microorganism groups that include bacteria, fungi, yeasts, protozoa and viruses. Due to their diversity and pathogenesis, bacteria are by far the most important microbial group and commonly associated with food-transmitting diseases

Bacteria are microorganisms largely spread throughout the natural world and may be found in every type of environment [14]. They cause diseases in humans, animals and plants and deteriorate food and other materials. On the other hand, they may be useful too when they compose the human being's normal microbiota and are used in the production of food as symbiotic in agriculture and medicine.

In spite of certain unreliable Brazilian statistics, it is believed that food-derived diseases in Brazil are high [15]. In fact, several studies estimate that $12 \%$ of hospitalization cases in Brazil occur because of infectious intestinal diseases [16].

Occurrences of food-derived diseases are normally associated with certain risk factors, or rather, procedures that benefit toxin infections. The following may be highlighted: faults in food refrigeration; conservation of warm food at room temperature; food prepared many hours earlier for later consumption with inadequate conditioning during the interval; faults in the cooking process; handling of food by people with inadequate personal hygiene practices, or with lesions or with contaminating diseases; usage of contaminated prime matter; faults in the hygiene of utensils and other equipments in food preparation; favorable environmental conditions for the growth of etiological agents; food obtained from unreliable sources; inadequate storage; use of utensils which release toxic residues; intentional or accidental addition of toxic chemicals to the food; usage of water with uncontrolled drinkability features; water contamination from damages in the supply system [17]. 
Problems in the manufacture of cheese in Brazil are related to precarious conditions of milk, bad conditions during the manhandling of cheese and the lack or deficiency of refrigeration throughout the production chain. These factors worsen the situation and establish contamination conditions which favor the development of microorganisms at several places [18].

Whereas some microorganisms contribute beneficently towards the processing, safety and quality of certain food products, other organisms are involved in processes with unwanted effects in food and for the consumers' health. There are two categories of food-transmitted microbial diseases: food intoxication and infection by food. In food intoxication, the person ingests toxins that are pre-formed by microorganisms in the food. The toxin causes damage to the organism. Examples comprise botulinum toxin that binds itself to the nerve terminals at the muscle level and impedes the release of acetylcholine neurotransmitter, and staphylococcus toxin that acts on the brain's vomiting-center [19]. Infection by food occurs when the pathogen, such as by Salmonella typhy and other serotypes, is ingested and multiplies itself, causing diseases in the intestine tract and often in other organs [20].

The sale of animal-derived food in fair stalls without any refrigeration and without any protection against dust and insects may alter their quality. In the case of cheese, it is sold in portions or slices and thus the external incorporation of biological or non-biological foreign matter is dangerous due to faults in the handling of the product during commercialization, poor hygiene of the stalls and utensils used, and crossed contamination between exposed products [21].

Food microbial contamination is unwanted and dangerous within food microbiology. This aspect should be faced with great strictness. The acknowledgement of possible hygiene deficiency implying in food contamination brings to the fore microorganism groups, comprising indicators, and pathogenic microorganisms that find an excellent environment in food for their development and even for the release of toxic substances [22]. Total and thermotolerant coliforms, such as Staphylococcus aureus, fungi, yeasts and even Salmonella spp., should be highlighted among the microorganisms whose presence and numbers indicate the quality of the product.

The above mentioned microorganisms, causes of several types of pathogenesis, are transmitted to humans because of lack of hygiene, bad habits of handlers, inefficient production processes, maintenance or re-heating of food at inadequate temperatures and also by non-adequate conditions in industries where the food is produced [23].

Most microorganisms, whose pathogenicity in humans depends on their variegated presence in food, are relatively sensitive to high temperatures. In fact, they are destroyed by the adequate cooking of eventually contaminated food or by pasteurization processes.

The Brazilian Agency for Health Vigilance (ANVISA) established, by Decree RDC 12 of the 2nd January 2001[24], the microbiological Standards for several types of food, described in Table 1.

So that food-caused disease cases and events could be characterized, the populations should be informed on the symptoms of each, such as mild diarrheas and vomiting since these are considered as a "passing illness" and not necessarily associated with food consumption [25]. 


\begin{tabular}{ll}
\hline Microorganism & Quantity \\
\hline Coliforms at $45^{\circ} \mathrm{C}$ & $5 \times 10^{2} \mathrm{MPN} / \mathrm{g}$ \\
\hline Staphylococcus aureus & $5 \times 10^{2} \mathrm{CFU} / \mathrm{g}$ \\
\hline Salmonella sp. & Absence in $25 \mathrm{~g}$ \\
\hline
\end{tabular}

* MPN (most probable number), CFU (colony forming unit). Source: ANVISA/2001[24]

Table 1. Microbiological Standards for Food: cheese with high moisture (55\%).

According with registers, more than a billion cases of acute diarrhea are detected in lessthan-5-year-old children in developing countries yearly, with 5 million deaths. Between 1999 and 2001, in the state of Paraná, Brazil, 67.1\% of food epidemics were caused by bacteria. Moreover, out of 1389 notified epidemics, 38.6 were confirmed in the laboratory; $29 / 7 \%$ were confirmed clinically or epidemiologically suspect and $31.6 \%$ were of unknown etiology [25].

World cheese production is slightly above 19 million tons. Cheese production increased more than $76.3 \%$ during the last thirty years, or rather, from approximately 10.8 million tons in 1978 to more than 19 millions in 2008. The expansion of milk-producing regions and production increase throughout recent years provided a highly relevant presence of Brazilian production within the world market of milk-derived exports. Concern is therefore high with regard to the quality of commercialized goods for internal and external consumption.

Family-run agriculture in Brazil has an important share in the milk production chain, with approximately $86 \%$ of milk producers. However, the production and management of these milk producers are foregrounded on a homemade basis with scanty technical assistance and high influence of cultural factors that may put to risk consumers' health. Technical and educational orientation through the introduction of healthy manufacturing practices are deemed necessary to minimize contamination risks and food intoxication by the product.

Research in all Brazilian regions, where the production and commercialization of cheese is undertaken mainly by small producers, has demonstrated the risk of toxin infections in the consumption of these products by the population.

The curd-cheese is the most produced and consumed milk-derived product in the northeastern region of Brazil. Several investigations [26] have shown that the handling and carelessness in hygiene within the production system have made it foremost as a contamination source. The manufacturers are transmission vectors of the pathogen Staphylococcus aureus and others that may cause food intoxication. The presence of positive coagulase staphylococcus witnesses the lack of hygiene and sanitary conditions during the production, processing, distribution, storing and commercialization stages of samples of curd-cheese. Sanitary education of the producers and the spreading of processing techniques based on good manufacturing practices are mandatory.

Researches in the state of Mato Grosso, in the Mid-Western region of Brazil, (Loguercio \& Aleixo 2001) [27] have shown the poor hygiene and sanitary conditions that characterize the 
production of fresh Minas cheese. Staphylococcus aureus bacteria rates higher than those permitted by current legislation are rife. The need for more sanitary surveillance and orientation by government authorities is urgent.

Research work in the southeastern region of Brazil [28] (Salotti et al 2006) evaluated the microbiological quality of fresh Minas cheese samples. Results from the hinterlands of the state of São Paulo, Brazil, showed non-compliance to rules established by the Brazilian Agency for Sanitary Vigilance (ANVISA) for $83.4 \%$ of homemade products and $66.7 \%$ for industrial samples with regard to thermotolerant coliforms. In the case of positive coagulase Staphylococcus, $20 \%$ of homemade samples and $10 \%$ of industrial products failed to comply with the ANVISA regulations. Microbiological results revealed the potential risk of the product for consumers.

After analyzing samples of fresh Minas cheese in Minas Gerais for coliforms and E. coli, a recent study [29] showed the presence of microorganisms, above the rates allowed by current legislation, in $30 \%$ of cheese with certificate; $70 \%$ of cheese without certificate and $61.4 \%$ of mild cheese. Since E. coli, Proteus, Providencia, Serratia, Klebsiella and Enterobacter were identified within the Enterobacteriaceae isolated in fresh Minas cheese, the risk to public health when the products are consumed is amply demonstrated.

Was reported [30] on the risk in the consumption of fresh Minas cheese by the population of the state of Paraná, southern Brazil. Samples inspected by the Federal Inspection Service of Santa Helena PR Brazil revealed that only 15\% were in accord to ANVISA standards. All homemade cheese samples and $70 \%$ of inspected ones were not according to legislation. Studies [31] confirmed the above results and reported that $50 \%$ of samples of analyzed cheese had thermotolerant coliforms, $100 \%$ had positive coagulase Staphyloccocus and $12.5 \%$ had Salmonella sp. These samples were inadequate for human consumption since they were not consonant to cheese microbiological standards.

\section{Microbiological contaminants of jerked beef}

One of the most traditional products of the northeastern region of Brazil is jerked beef which may be characterized as a nutrition food with high calorie rates and widely accepted by consumers for its peculiar sensorial features. Jerked beef is produced from cuts derived from all parts of cattle carcass, salted and dried, with longer durability when compared to that of fresh meat [32].

Due to different nomenclature in Brazil, such as 'carne-de-sertão', 'carne serenada', 'carne deviagem', 'carne-mole', 'carne-do-vento', 'cacina' or more simple still, dehydrated meat, jerk beef is often confused with another type of salted beef, albeit industrialized, called 'charque' or dried salted meat [33].

Jerked beef was first used in the northeastern region of Brazil as an alternative to preserve beef surplus which could not be consumed immediately and so that the meat would not deteriorate quickly due to difficulties in its preservation especially among the poor population with no 
refrigeration equipments. Favorable climate conditions and availability of seawater salt, fresh meat could be preserved by being dehydrated and salted.

Currently the above-mentioned preservation process is less relevant due to the introduction of refrigeration. However, many people from different regions of Brazil, especially from the northeast, became accustomed to the produce's characteristic taste and continued to produce jerked beef will less amounts of salt and frequently without exposure to the sun.

Each Brazilian state developed its own technology and thus produced jerked beef with different characteristics with regard to aspect, taste, color, amount of salt and shelf life. The states of Rio Grande do Norte and Ceará are the greatest producers of jerked beef mainly due to climatic conditions that favor the food's dehydration. In fact, jerked beef passed from a locally consumed product and used in certain food receipts to wider conditions. In fact, it is appreciated throughout Brazil and in several meal preparations. Jerked beef may be found in big city centers such as São Paulo and Rio de Janeiro, in homes and restaurants, outside the restricted circle of northeastern cuisine [34], and in the menu of the poorest worker $[35,36]$.

Owing to the popularization of homemade salting technique, jerked beef production follows typically regional norms. Consequently, it is produced in a highly rudimentary way under inadequate sanitary conditions [37,38]. Analysis of the hygiene conditions in the production and commercialization of jerked beef in the region of Itapetinga BA Brazil may be brought forward as an example of the popularization of the technique. In fact, $73.3 \%$ of the shopkeepers interviewed admitted that they themselves produced the jerked beef on sale in their shops. Whereas $63.6 \%$ used non-inspected meat, $27.3 \%$ used meat inspected by municipal health officers and only $0.1 \%$ was inspected by federal health officers. Jerked beef was stored and commercialized in $71 \%$ of the shops at room temperature, which favored the multiplication of contaminant microorganisms and flies. These facts bring health risks to consumers and jeopardize the product's physical aspects [39].

Salting technique consists in the removal of water from the meat tissues; decrease in water activity ensues, inhibits microbial development and the speed of unwanted reactions of the final product. When salted beef is conserved without any type of refrigeration, its shelf life is higher than that of fresh meat [40]. However, jerked beef has low sodium chloride ( $\mathrm{NaCl})$ rates, between 5 and $6 \%$, high moisture, between 65 and $70 \%[35,41,42]$ and water activity of 0.92 . It may be characterized as partially dehydrated meat in which water activity is not sufficient decreased to avoid microbial development (and consequently degradation) or the production of microbial toxins $[43,44]$.

Although the literal translation of the jerked beef in Portuguese is 'meat exposed to the sun', it is actually only rarely exposed to the sunrays during the dehydration process. The end product is a semi-dehydrated homemade product with four-day shelf-life at room temperature and up to eight days under refrigeration $[43,45,41]$.

Data on the physical and chemical qualities of jerked beef sold in butcheries and supermarkets in João Pessoa PB Brazil showed that water activity in all samples was relatively high, between 0.898 and 0.967 , and that the rates of sodium chloride $(\mathrm{NaCl})$ ranged 
between $3.73 \%$ and $9.79 \%$. Consequently, $\mathrm{NaCl}$ employed in the process was insufficient to decrease water activity in the product and thus it did not have a significant inhibitory action in the development of most microorganisms in the beef [46]. Lack of standardization in the quality of jerked beef was also assessed in samples collected at inspected shops. Mean rates of water activity were $0.94 \pm 0.02$. The same average was obtained for samples collected in shops without any health inspection [47]. Variations in sodium chloride rates were also registered in the samples. Techniques for more efficient conservation are required to decrease such risks since it is a type of food with contamination possibilities throughout the manufacturing process.

With regard to the microbiological contamination of jerked beef, the transformation by which meat in natura is processed into jerked beef requires that technological alterations modify the initial microbiota by which the salting and dehydration process selects more tolerant microorganisms for such conditions [48]. Pathogens that may contaminate jerked beef comprise Clostridium perfringens, Staphilococus aureus, Salmonella, verotoxin-producing Escherichia coli, Campylobacter, Yersinia enterocolitica, Listeria monocytogenes, Aeromonas hydrofila, and other deteriorating bacteria [49]. However, low $\mathrm{NaCl}$ rates used in jerked beef is one of the factors that trigger microbiological development since decrease in water activity is insufficient to hinder the development of deterioration-producing bacteria of the genus Pseudomona. It also provides proper conditions for the growth of gram-positive bacteria as those of the genus Staphylococcus [38].

Samples of jerked beef from the north of the state of Minas Gerais, Brazil, showed that the amount of mesophile aerobic bacteria, an index of food hygiene quality, was between 2.0x104 UFC/g and 8.9x108 UFC/g. Psichrotrophic bacteria were found in 93.33\% of samples, between $5.4 \times 103 \mathrm{UFC} / \mathrm{g}$ and $2.9 \times 106 \mathrm{UFC} / \mathrm{g}$. Results show poor hygiene in the manufacture of jerked beef [50]. Similar results were reported in samples of jerked beef commercialized in João Pessoa where the number of mesophile bacteria ranged between $1.8 \times 105$ and $7.5 \times 107 \mathrm{UFC} / \mathrm{g}$, with a clear correlationship between mesophile contamination and hygiene and sanitary standards [42].

High thermotolerant coliform rates, which also demonstrate unsatisfactory hygiene and sanitary conditions during the processing stages in the manufacture of jerked beef, were also registered in most jerked beef samples sold in butcheries and supermarkets in João Pessoa PB Brazil [46]. However, total coliforms in food did not report recent fecal contamination or the occurrence of enteropathogens [51,52]. However, Brazilian sanitary laws did not regulate the presence of this microorganism group in meat.

The commercialization of jerked beef in health inspected or not in the region of João Pessoa PB Brazil has been evaluated and results showed high rates in both groups. Ninety-six samples were analyzed and high contamination by feces-derived microorganisms was reported. Staphylococcus ssp. rates were high in both groups, with a low frequency for S. aureus [47]. Staphylococcus aureus rates were higher than $5 \log U F C / \mathrm{cm} 2$ in $50 \%$ of jerked beef samples commercialized in butcheries and supermarkets in João Pessoa PB Brazil. The above amounts demonstrate high contamination causing gastrointestinal disorders in consumers [53]. 
Mesophile microorganisms Salmonella sp. and Staphylococcus aureus in jerked beef commercialized at room temperature and under refrigeration in Campina Grande PB Brazil showed no significant difference in $S$. aureus counts for samples commercialized at room temperature and under refrigeration. Salmonella ssp. was detected in $40 \%$ of jerked beef samples commercialized at room temperature and in $30 \%$ of samples under refrigeration.

Another source of contamination in the commercialization of jerked beef may be found in supermarkets, open market stalls and butcheries. Data reveal that the utensils used in $75 \%$ of these outlets were not exclusively for meat cutting and that the handling of money and food was common practice in $25 \%$ of the businesses. Aprons, disposable caps and clean closed shoes were only found in $25 \%$ of the shops.

The inadequate washing of hands and other habits such as talking during the handling and commercialization of food were also reported in all commercial enterprises [54]. It has been verified that in João Pessoa, supermarkets had the best hygiene and sanitary profile in jerked beef quality, whereas open markets and stalls in fairs had the worst [42]. In the latter case, meat is exposed without any type of protection and any passerby may handle it at will.

Investigations were carried out with regard to alien matter, such as flies, acarids, larvae, insects, feathers and others, found in jerked beef sold in 20 (90.9\%) shops in Diadema SP Brazil, specialized in typical products from the northeastern region of Brazil. Exposure of products without any wrappings is an excellent condition for attacks by insects, especially flies, and rodents, making it improper for human consumption in the wake of health-hazard matter [55].

Almost all jerked beef is manufactured and sold in small shops and specifically prepared for people who appreciate the product. Consequently, lack of sanitary rules for its production, precarious conditions in its commercialization, storage without refrigeration and its exposure without any protection characterize jerked beef in such conditions as haphazard to public health.

\section{Microbiological contaminants in meat fillings (sausages made from beef and fowl meat, salami)}

Animal-derived food conveys a host of microorganisms dangerous to human health. The incidence of toxin infections in Brazil is high, although statistics are rather lacking on the matter. Bacteria causing toxin infections are widely distributed although their main natural habitat is the human or animal intestine tract [14]. The most common bacteria in food contamination are of the genera Escherichia, Salmonella, Shigella, Yersinia, Vibrio, Brucella, Clostridium, Listeria, Campylobacter, Bacillus cereus and Staphylococcus aureus [56]. Sausages, widely used in Europe, is a type of food stuffed with meat from swine, fowls, goats, cattle and fish, seasoned with several types of spicy ingredients. Sausages are a highly popular food in Brazil, easily accessible to all classes of people and consumed 
throughout the country. Sausages have great acceptance in the southern and southeastern regions due to a more Europeanized culture.

Brazilian swine breeding has a very important role in several sectors of Brazilian economy. It produces jobs and intensifies demand of agricultural products in the industrialization and commercialization of animal-derived products. Besides providing excellent animal protein to the population, the meat industry exports meat and important economical assets are aggregated [57].

Data by the Brazilian Association of Production and Exportation Industry of Pork (ABIPECS) showed that approximately $65 \%$ of the Brazilian pork production is directed towards the internal market through industrialized products. Among the processed products, the fresh Tuscan-type sausage, made exclusively from pork, uses the less important animal parts as food, with great acceptance among the population.

Pork and its derived products undergo bacterial alterations owing to several factors such as animal health and fecal contamination by Escherichia coli highly relevant worldwide as a microorganism hazardous to animal and population health involving hygiene and sanitary issues [57]. The same author evaluated the occurrence of E.coli in swine in the abattoirs of Rio de Janeiro, Brazil, from which the Tuscun-type sausages were made. Different parts of the animal used in the stuffing process were examined and concluded that, depending on the meat and the manufacturing process, sausages were not fit for consumption.

Toxoplasma gondhii in fresh pork sausages commercialized in Botucatu SP Brazil was evaluated by researches [58]. Pork represents one of the main sources of infection by $T$. gondii in humans. Swine were the most important animals in the process of toxoplasmosis transmission $[59,60,58,61]$. Mendonça's data did not show any evidence of T. gondii in the samples, perhaps due to salt, used in the manufacturing process, which eliminated the microorganism.

The occurrence of food infection by pork sausages contaminated with Salmonella sp. has been suggested [62]. Brazilian sanitary laws [63] make it mandatory that the microorganism should be lacking in $25 \%$ so that human intoxication may occur. However, such possibility may vary since it depends on serotype and the person's health conditions and tolerance. Mürmann's results [62] showed that $24 \%$ of pork sausages samples were contaminated by Salmonella enterica.

Contamination by Salmonella sp in pork may occur in pens through contact with feces, lack of hygiene and sanitation in the installations and by other animals during the transport, waiting or pre-finishing period. A high increase of $S$. enteriditis in food toxin infections in humans and in aviary products has been reported in Brazil since the 1990 [64].

Fecal coliforms, positive coagulase staphylococcus, Salmonella spp and Campylobacter spp in fresh sausages were evaluated [65]. When the hygiene and sanitary quality among the different types of fresh sausages was compared, pork sausages had the worst scores with regard to risks in public health, as ruled by the RDC n.12 of Anvisa [63]. 
The authors also registered that most samples were not in accordance to microbiological standards and thus hazardous to consumer's health. Another datum refers to the absence of Campylobacter spp in the samples, perhaps due to sodium chloride concentrations over $1.5 \%$ that may have inhibited these microorganisms.

Was analyzed [66] the presence of Listeria spp, principally L. monocytogenes, during the manufacture of fresh mixed-meat sausages in three abattoirs, supervised by state health authorities, in Pelotas RS Brazil. Results showed that all samples from the three abattoirs were contaminated by Listeria spp, of which the most frequent species was L. innocua (97.6), followed by $L$. monocytogenes $(29.3 \%)$ and L. welshimeri $(24.4 \%)$.

When the hygiene and sanitary conditions in the manufacture of fresh sausages in the northwestern region of the state of Paraná, Brazil, were analyzed [67] data failed to show any microbiological contamination that would jeopardize the health of the consumer. The manufacture of these samples followed strict handling and processing procedures.

On the other hand, another authors [68] studied the prevalence of antimicrobial resistance by serotypes of Salmonella isolated from fresh pork sausages and found significant quantities of the above in samples collected in the southern state of Santa Catarina, Brazil. These serotypes resisted the antimicrobial products sulfonamide and tetracycline (81\%); ampicillin (50\%) and chloramphenicol (31.25\%). Was evaluated the microbiological quality of fresh sausages in two towns of the state of Minas Gerais, Brazil [69]. Results confirmed positive coagulase Staphylococcus in $35 \%$ of samples which made them improper for human consumption. The same author also demonstrated that $35 \%$ of samples were contaminated by thermotolerant fecal coliforms above the maximum limits.

The consumption of chicken meat and its derivates has recently increased considerably in Brazil due to price decrease, good quality and practical cuttings provided [70]. Per capita consumption increased from $10 \mathrm{~kg}$ to $35.4 \mathrm{~kg}$, only slightly lower than beef consumption (União Brasileira de Avicultura) [71]. The products' quality is highly important and a great concern to health authorities, food industry and consumers. Chickens bred for human consumption may host several pathogenic microorganisms such as Campylobacter jejuni, Salmonella sp and E. coli $[72,73]$.

Rall investigated [70] the hygiene and sanitary conditions of chicken meat and several types of sausages commercialized in the interior of the state of São Paulo, Brazil, by determining the Most Probable Number of coliforms at $45^{\circ} \mathrm{C}$. The same authors also analyzed the presence of Samonella sp by the traditional method and by PCR. Data showed that $40 \%$ of the 75 sausage samples analyzed were improper for human consumption due to excess in coliforms and 7 samples (9.3\%) were positive for Salmonella sp. (9.3\%). Research by PCR increased to 56\% Salmonella-positive samples. When the frequency rate of Salmonella was added to the microbiological limits for coliforms, it might be concluded that $86.7 \%$ of sausages were improper for human consumption.

In their research in the northwestern region of the state of São Paulo, Brazil, others authors [74] found contamination by Salmonella in 16\% of chicken sausages samples. The most relevant item in the above result may be the handling of the product during processing, coupled to the 
exposure of the meat to several contamination sources or to already contaminated chickens that provided the contamination of the final product.

The above authors researched the microbiological quality of industrialized avian products and their derivates in another region of the state of São Paulo. Research determined the presence of Campylobacter jejuni and Salmonella sp. Sausages samples analyzed were $42.8 \%$ positive for C. jejuni and $28.5 \%$ for Salmonella sp.

The presence of microorganisms in the above research works suggests the need for greater care during the handling and preparation of sausages that may be eaten in natura, without any heating treatment that would reduce the number of microorganisms causing toxin infections [75].

Vienna sausage may be defined as an industrialized meat-stuffed product obtained from the emulsion of animal meat to which are added a variety of ingredients and condiments, filling a natural or artificial casing, and submitted to proper thermal process [76]. Vienna sausages are highly popular in Brazil due to their low costs and for the manufacturing of the ubiquitous hot dog.

The physical and chemical characteristics of Vienna sausages should contain a maximum of $65 \%$ moisture, $30 \%$ fat, $2 \%$ starch, $7 \%$ total carbohydrates, $12 \%$ protein. Fresh sausages should be under permanent refrigeration $\left(0^{\circ} \mathrm{C}\right.$ to $\left.5^{\circ} \mathrm{C}\right)$ from manufacture until consumption, with expiry period after 48 hours [77].

Vienna sausages samples of the hot-dog type were analyzed in Niterói and Rio de Janeiro RJ Brazil to detect thermotolerant coliforms, positive coagulase Staphylococcus, Clostridium spp and Salmonella spp by conventional methods with the necessary modifications [78]. When compared to health norms, results showed that $33 \%$ of samples were inadequate for consumption due to the presence of their isolated microorganisms.

Salami is another highly appreciated product in southern Brazil. Its homemade manufacture started in the early $20^{\text {th }}$ century with an enormous variety of industrialized types that differed in composition, casing, size of meat and fats, spices, smoking process and maturation period prior to commercialization. Researchers revaluated the various characteristics [79] of salamis produced by small- and medium-sized agro-industries in the southern state of Santa Catarina, Brazil. Bacteria Staphylococcus aureus, Salmonella spp, Listeria monocystogenes and E.coli were researched in the products. Although results did not identify contamination by Salmonella spp, the E. coli and S. aureus counts were significant, but within the reliability parameters.

Was analyzed the quality [80] of salami in the interior of the state of São Paulo, Brazil, and verified that, despite samples with E. coli and fecal coliforms, all samples were within health standards. Nevertheless, $60 \%$ of samples were contaminated by Staphylococcus aureus and $22 \%$ were unhealthy for consumption. 


\section{Final considerations}

Owing to their importance for public health, the correct handling of meat and milk products required greater attention, care and supervision from the competent health authorities. Since there is great cultural diversity in food manufactured in Brazil, the direct intervention of all the sectors involved within the food production chain is mandatory to warrant healthy and reliable products and thus a decrease in diseases caused by food contamination.

\section{Author details}

Suzymeire Baroni ${ }^{1}$, Izabel Aparecida Soares ${ }^{2}$, Rodrigo Patera Barcelos ${ }^{1}$, Alexandre Carvalho de Moura ${ }^{2}$, Fabiana Gisele da Silva Pinto ${ }^{3}$ and Carmem Lucia de Mello Sartori Cardoso da Rocha ${ }^{4}$

1 Veterinary Medicine -Federal University of Paraná-Palotina, Brazil

2 Federal University South Border- Realeza- Paraná, Brazil

3 State University of Western Parana, Centre for Science and Health, Brazil

4 University State of Maringá, Departament of Cell Biology and Genetics, Brazil

\section{References}

[1] Arcuri EF, Brito MAVP, Brito JRF, Pinto SM, Angelo FF, Souza GN, Qualidade Microbiológica do leite refrigerado nas fazendas. Arquivo Brasileiro Medicina Veterinária Zootecnia, Belo Horizonte, 2006; 58(3): 440-446.

[2] Lange CC, Brito, JRF. Inluência da qualidade do leite na manufatura e vida de prateleira dos produtos lácteos: papel das altas contagens microbianas. In: Brito, J.R.F; Portugal, JA (Eds.) Diagnóstico da qualidade do leite, impacto para a indústria e a questão dos resíduos de antibióticos. Empresa Brasileira de Pesquisa Agropecuária (Embrapa), Juiz de Fora, p. 117-138, 2003.

[3] Gomes HÁ, Gallo CR. Ocorrência de Staphylococcus aureus e produção de enterotoxinas por linhagens isoladas a partir de leite cru, leite pasteurizado tipo $\mathrm{C}$ e queijo Minas frescal comercializados em Piracicaba,SP. Revista Ciência e Tecnologia de Alimentos, 1995; 15( 2): 158-161.

[4] Gonçalves CA, Vieira LC. Obtenção e higienização do leite in natura. Empresa Brasileira de Pesquisa Agropecuária (EMBRAPA). Amazônia Oriental, Belém: Documento 141. 2002. 28p. 
[5] Olivieri D. de A. Avaliação da qualidade microbiológica de amostras de mercado de queijo mussarela, elaborado a partir do leite de búfala (Bubalus bubalis). 61 p. Dissertação (Mestrado) - Escola Superior de Agricultura Luiz de Queiroz, Piracicaba, SP, 2004.

[6] Huhn S, Hajdenwurcel JR, Moraes JM de, Vargas OL. Qualidade microbiológica do leite cru obtido por meio de ordenha manual e mecânica e ao chegar à plataforma.Revista do Instituto de Laticínios Cândido Tostes, 1980; 35(209): 3-8.

[7] Brasil. Ministério da Agricultura, do Abastecimento e da reforma Agrária. Portaria n. 146, de 07 de março de 1996. Diário Oficial da União, Seção I, Brasília, DF, p 3977-3886, 1996.

[8] Vieira DAS, Neto JPM. Elaboração de queijos frescais em pequena escala. Informe Agropecuário, 1982; 8(88): 28-29.

[9] Loguercio AP, Aleixo JAG. Microbiologia de queijo tipo Minas Frescal produzido artesanalmente. Ciencia Rural, 2001;31(6): 1063-1067.

[10] Hoffman FL, Cruz CHG, Vinturim TM. Qualidade microbiológica de queijos comercializados na região de São José do Rio Preto, SP. Revista do Instituto de Laticínios. Cândido Tostes,1995; 50: 42-47.

[11] Furtado MM, Mosquim MCA, Fernandes AR, Silva CAB da. Laticínios diversificados. In: Silva CAB da, Fernandes AR. Projetos de empreendimentos agroindustriais: produtos de origem animal. Viçosa: UFV, 2003. 308p.

[12] Almeida Filho ES. Características microbiológicas do queijo Minas frescal, produzido artesanalmente e comercializado no Município de Poços de Caldas, MG. Dissertação (Mestrado) - Faculdade de Ciências Agrárias e Veterinárias, Campus de Jaboticabal da UNESP; 1999.

[13] Pinto PSA, Germano MIS, Germano PML. Queijos minas: problemas emergentes de vigilância sanitária. Revista Higiene Alimentar,1996; 10(44): 22-27.

[14] Cunha CP, Nascimento MGF, Jesus VLT, Nascimento ER, Corbia ACG. Queijo tipo minas frescal com e sem serviço de Inspeção Federal - Contaminação por coliformes fecais e Escherichia coli. V Congresso Brasileiro de Higienistas de Alimentos. Foz de Iguaçu, PR, 1999. Revista Higiene Alimentar,1999; 13(61): 34-35.

[15] Franco, GMB, Landgraf, M. Microbiologia dos alimentos. São Paulo: Atheneu; 1996.

[16] Santos, TBA, Balioni, GA, Soares, MMSR, Ribeiro, MC. Condições higiênico-sanitárias de alfaces antes e após tratamento com agentes antibacteriano. Revista Higiene Alimentar, 2004; 18(121): 85- 88.

[17] Nascimento, MS, Silva, N, Catanozi, MPLM. Avaliação microbiológica de frutas e hortaliças frescas, comercializadas no município de Campinas, SP. Revista Higiene Alimentar, 2003;17( 114): 73-76.

[18] CENEPI/FUNASA/MS. Manual integrado de prevenção e controle de doenças transmitidas por alimentos, 2001. 
[19] Lisita, MO. Evolução da população bacteriana na linha de produção do queijo minas frescal em uma indústria de lacticínios. 61 p. Dissertação (Mestrado) - Escola Superior de Agricultura Luiz de Queiroz, Piracicaba, SP, 2005

[20] Silva, JEAE. Manual de controle higiênico sanitário de alimentos. São Paulo: Varela; 1999

[21] Trabulsi, LR. Microbiologia. São Paulo: Atheneu; 1999.

[22] Correia, M, Roncada, M.J. Características microscópicas de queijo prato, mussarela e mineiro comercializados em feiras livres da Cidade de São Paulo. Revista de Saúde Pública, junho 1997; 3 (31).

[23] Franco, RM, Almaida, LEF. Avaliação microbiológica de queijo ralado, tipo parmesão, comercializado em Niterói, RJ. Revista Higiene Alimentar, 1992; 6(21): 33-36.

[24] Brasil, Agência Nacional de Vigilância Sanitária (ANVISA). Resolução RDC no 12 de 02 de Janeiro de 2001.

[25] Silva, LF. Procedimento operacional padronizado de higienização como requisito para segurança alimentar em unidade de alimentação. Dissertação (Mestrado em Ciência e Tecnologia de Alimentos) - Universidade Federal de Santa Maria, RS, 2006.

[26] Tigrel, DM, Borelly, MAN. Pesquisa de Estafilococos coagulase-positiva em amostras de "queijo coalho" comercializadas por ambulantes na praia de Itapuã (Salvador-BA). Revista Ciências medica e biologia, 2011;.10(2): 162-166.

[27] Loguercio, AP, Aleixo, JAG. Microbiologia de queijo tipo minas frescal produzido artesanalmente. Ciência Rural, 2001; 31(6).

[28] Salotti, BM, Carvalho, ACFB, Amaral, LA, Vidal-Martins, AMC, Cortez, AL. Qualidade Microbiológica do queijo minas frescal comercializado no município de Jaboticabal, SP, Brasil. Arquivos do Instituto Biologico, 2006;73 (2): 171-175.

[29] Okura, M.H. Avaliação microbiológica de queijo tipos minas frescal comercializados na região do triângulo mineiro Tese (Doutorado em Microbiologia) - Tese (doutorado) - Universidade Estadual Paulista, Faculdade de Ciências Agrárias e Veterinárias, 2010.

[30] Pinto, FGS, Souza, M, Saling, S, Moura, AC. Qualidade microbiológica de queijo Minas Frescal comercializado no Município de Santa Helena, PR, Brasil. Arquivos do Instituto Biológico, 2011; 78 (2): 191-198.

[31] Oliveira, DF, Tonial, CEC. Sazonalidade como fator interferente na composição físicoquimica e avaliação microbiológica de queijos coloniais. Arquivo Brasileiro de medicina veterinária e zootecnologia, 2012; 64(2): 521-523.

[32] Vasconcelos O. Por cima da carne seca. Revista Globo Rural, 1986; 1 (5): 15-20.

[33] Lira GM, Shimokomaki M. Parâmetros de qualidade da carne de sol e dos charques.Higiene Alimentar, São Paulo,1998; 44 (13): 66-69. 
[34] Serviço de Informação da Carne [SIC]. Charque, carne de sol, carne seca. Desenvolvido pelo Comitê Técnico do SIC. São Paulo. Disponível em: http://www.sic.org.br/charque.asp (Acesso 14 de agost 2012).

[35] Nóbrega DM, Schneider I S. Contribuição ao estudo da carne de sol visando melhorar sua conservação. Revista Higiene Alimentar. 1983; 2(3): 150-4.

[36] Gouvêa JAG, Gouvêa AAL. Tecnologia de fabricação da carne de sol. Bahia: Rede de Tecnologia da Bahia- RETEC/BA, 2007. 23 p. Dossiê Técnico.

[37] Menucci TA. Avaliação das condições higiênico-sanitárias da carne de sol comercializada em "casas do norte" no município de Diadema- SP. 2009. 121 f. Dissertação (Mestrado em Saúde Pública) - Faculdade de Saúde Pública, Universidade de São Paulo, São Paulo, 2009.

[38] Azevedo PRA, Morais MVT. A tecnologia da produção da carne de sol e suas simplificações nos aspectos higiênico-sanitários. Revista Nacional da Carne, São Paulo, 2005; 29(98): 12-13.

[39] Ramos ALS, Ramos EM, VIANA EJ. Avaliação das condições higiênicas na produção e comercialização da carne de sol na região de Itapetinga, BA. Revista Higiene Alimentar, 2007; 21(150): 371-374.

[40] Picchi, V, Cia G. Fabricação do charque. Boletim do Centro de Tecnologia de Carnes, 1980; 5: 11-30.

[41] Shimokomaki M, Olivo R. Suplementação de vitamina e melhora a qualidade de carnes e derivados. In: Shimokomaki, M. et al. (Ed.). Atualidades em ciência e tecnologia de carnes. São Paulo: Varela, 2006. cap. 11, p. 115-121

[42] Farias SMOC. Qualidade da carne de sol comercializada na cidade de João Pessoa-PB, Dissertação de Mestrado- UFPB/CT, 142f. 2010.

[43] Lira GM, Shimokomaki M. Parâmetros de qualidade da carne de sol e dos charques. Revista Higiene Alimentar. 1998; 12(58): 33-5.

[44] Felicio PE. Carne de sol - Produto artesanal, de consumo regional, tem potencial para ser fabricado e comercializado no país todo. ABCZ, 2002.

[45] Costa EL, Silva JA. Avaliação Microbiológica da carne de sol elaborada com baixos teores de cloreto de sódio. Revista Higiene Alimentar 2001; 21(2): 149-53.

[46] Costa EL, Silva JA. Qualidade sanitária da carne de sol comercializada em açougues e supermercados de João Pessoa - PB. Bol. CEPPA. Curitiba. 1999; 17(2): 137-44

[47] Costa EL, Silva JA. Avaliação Microbiológica da carne de sol elaborada com baixos teores de cloreto de sódio. Revista Higiene Alimentar. 2001; 21(2): 149-53.

[48] Maca JV, Miller RK, Acuff, GR. Microbiological, sensory and chemical characteristics of vacuum-packaged ground beef patties treated withs salts of organic acids. Journal of Food Science, Chicago,1997; 62(3): 591-596. 
[49] Gill CO. Microbiological contamination of meat during slaughter and butchering of cattle, sheep and pigs. In: The microbiology of meat and poultry. Londres: Blackie Academic \& Professional, 1998. cap. 4, p. 119-157

[50] Cruz ALM. Produção, comercialização, consumo, qualidade microbiológica e características físico-químicas da carne de sol do Norte de Minas Gerais, Dissertação de Mestrado,Montes Claros, MG: ICA/UFMG, 2010.

[51] Franco BDGM, Landgraf, M. Microrganismos patogênicos de importância em alimentos. In: Microbiologia dos alimentos. São Paulo: Atheneu, 2008. cap. 4, p. 33-82.

[52] Silva N, Junqueira VCA, Silveira NFA, Tanawaki MH, Dos Santos, R S, Gomes R A R. Manual de Métodos de Análise Microbiológica de Alimentos. $4^{\circ}$ edição. São Paulo. Ed. Livraria Varela, 2010.

[53] Costa EL, Silva JA. Qualidade sanitária da carne de sol comercializada em açougues e supermercados de João Pessoa - PB. Bol. CEPPA Curitiba 1999; 17(2): 137-44.

[54] Miranda PC, Barreto NSE. Avaliação Higiênico-Sanitária de diferentes Estabelecimentos de Comercialização da Carne-de sol no Município de Cruz Das Almas-Ba. Revista Caatinga, Mossoró, 2012; 25(2): 166-172.

[55] Mennucci TA, Marciano MAM, ATUI, MB, Polineto A, Germano PML. Study on contaminant materials within "sun dried meat (jerked beef)" at the "Northern Houses. Revista Instituto Adolfo Lutz 2010; 69(1): 47-54.

[56] Pinto A. Doenças de origem microbiana transmitidas pelos alimentos. Millenium 1996; (4): 91-100.

[57] Franco R. E.coli: ocorrência em suínos abatidos na grande Rio e sua viabilidade experimental em linguiça frescal tipo toscana.Tese doutorado. Universidade Federal Fluminense; 2002.

[58] Mendonça A O. Detecção de Toxoplasma gondii em linguiças comercializadas no município de Botucatu- SP. Tese doutorado. Universidade Estadual Paulista Julio Mesquita Filho; 2003.

[59] Durbey J P. Refinemente of pepsin digestion method for isolation of Toxoplasma gondii from infected tissues. Veterinary Parasitology 1998; 74: 75-77.

[60] Gamble HR, Murrel KD. Detection of parasites in food. Parasitology 1998; (117): 97-111.

[61] Tenter A M. Current knowledge on the epidemiology of infections with Toxoplasma. The Tokai Journal of Experimental and Clinical Medicine 1998; 23 (6): 391.

[62] Mürmann L. Avaliação do risco de infecção por Salmonella sp em consumidores de linguiça frescal de carne suína em Porto Alegre -RS. Tese doutorado. Universidade Federal do Rio Grande do Sul; 2008.

[63] Brasil. Agência Nacional de Vigilância Veterinária. Resolução nำ12 de 12 de janeiro 2001. Regulamento técnico sobre os padrões microbiológicos para alimentos. 2001. Dis- 
ponível: http:/WWW.anvisa.gov.br/Regis/resol/12_oirac.num. (Acesso: 10 agosto 2012).

[64] Fuzihara T O, Fernandes S A, Franco B D. Prevalence e dissemination of Salmonella serotypes along the slaughtering process in Brazilian small poultry slaugtherhouses. Journal Food Protection 2000; 63: 1749-1753.

[65] Cortez A L L, Carvalho A C F B; Amaral L A, Salotti B M, Vidal-Martins A M C. Coliformes fecais, Estafilococos coagulase positiva (ECP) e Campylobacter ssp em linguiça frescal. Alimentos Nutrição. 200415 (3): 215-220.

[66] Silva W P, Lima A S, Gandra E A, Araújo M R, Macedo M R P, Duval E H. Listeria spp. no processamento de linguiça frescal em frigoríficos de Pelotas, RS, Brasil. Ciência Rural 2004; 34 (3): 911-916.

[67] Corazza M L, Mantovani D, Filho L C, Costa S C. Avaliação higiênico-sanitária de linguiças tipo frescal após inspeção sanitária realizada por órgãos federal, estadual e municipal na região noroeste do Paraná. Revista Saúde e Pesquisa 2011; 4 (3): 357-362.

[68] Spricigo D A, Matsumoto S R, Espindola M L, Vaz E K, Ferraz S M. Prevalência e perfil de resistência antimicrobianos de sorovares de Samonella isolados de linguiças suínas tipo frescal em Lages, SC. Arquivo Brasileiro Medicina Veterinária e Zootecnia 2008; 60 (2): 517-520.

[69] Marques S C, Boari C A, Brcko C C, Nascimento A R, Picolli R H. Evaluation of hygienical-sanitary type frescal commercialized in the cities of Três Corações and LavrasMG. Ciência Agrotecnologia 2006; 30 (6): 1120-1123.

[70] Rall V L M, Prado J G, Candeias J M G, Cardoso K F G, Rall R, Araujo Junior J P. Pesquisa de Salmonella e das condições sanitárias em frangos e linguiças comercializadas na cidade de Botucatu. Brazilian Journal Veterinary Research Animal Science Brazilian. Journal. 2009; 46(3): 167-174.

[71] União Brasileira de Avicultura. Relatório anual 2005-2006. Disponível em ๑ http:// www.uba.org.br/ubanews_files/rel_uba_2005_06.pdf® (Acesso em: 23 jul.2012).

[72] Lucey B, Feurer C. Greer P, Moloney P, Cryan B, Fanning S. Antimicrobial resistence profiling and DNA amplification Fingerprint (DAF) of thermophlic Campylobacter spp in human, poutry and porcine samples from Cork region of Ireland. Journal of Applied Microbiology 2000; 89 (5): 727-734.

[73] Natrajan N, Sheldon B W. Inhibition of Salmonella on poultry skin protein and polysaccharide-based films containing a nisin formulation. Journal of Food Protection 2000; 63 (9): 1268-1272.

[74] Carvalho A C F B, Cortez A L L. Samonella spp in carcasses, mechanically deboned meat sausages and chiken meat. Ciência Rural 2005; 35 (6): 1465-1468. 
[75] Carvalho A C F B, Cortes A L L. Contaminação de produtos avícolas industrialização e seus derivados por Campylobacter jejuni e Salmonella sp. Arquivo Veterinária 2003; 19 (1): 057-062.

[76] Brasil, Ministério da Agricultura, Pecuária e Abastecimento. Secretaria de Defesa Agropecuária - MAPA/SDA. Instrução Normativa № 4 de 31 de março de 2000.-Aprova os Regulamentos Técnicos de Identidade e Qualidade de Carne Mecanicamente Separada, de Mortadela, de Lingüiça e de Salsicha -Diário Oficial da União, Brasília, DF, p.6, de 05 de abril de 2000. Seção 1.

[77] Ferreira M C, Fraqueza M J, Barreto A S.Avaliação do prazo de vida útil da salsicha fresca. Revista Portuguesa de Ciências Veterinárias 2007; 102 (561): 141-143.

[78] Martins L L, Santos J F, Franco R M, Oliveira L A T, Bezz J. Bacteriological study in bovine and chikem hot dog type- sausages sold in vacuumed packing-case and retail commercialized in Rio de Janeiro city and Niterói, RJ/ Brazil supermarkets. Revista. Instituto. Adolfo Lutz 2008; 67 (3): 215-220.

[79] D'Agostini F P, Campana P, Degenhart R. Qualidade e identidade de embutidos produzidos no baixo Vale do Rio do peixe, Santa Catarina- Brasil. E. Tech Tecnologias para Competitividade Industrial 2009; 2 (2): 1-13.

[80] Hoffmann F L, Garcia-Cruz C H, Vinturim T M, Carmello M T. Qualidade microbiológica do salame. B. Ceppa 1997; 15 (1): 57-64. 